\title{
An unusual facial enlargement
}

\author{
Benjamin Dallaudière - Julien Lincot • Anne Cotten • \\ Elisabeth Schouman-Claeys
}

Published online: 10 July 2012

(C) ISS 2012

\begin{abstract}
Answer
Leontiasis ossea secondary to chronic kidney disease.
\end{abstract}

\section{Discussion}

This finding is typical of leontiasis ossea, a rare craniofacial manifestation of azotaemic osteodystrophy classically complicating chronic kidney disease but sometimes associated with other osseous disorders such as fibrous dysplasia and Paget's

The case presentation can be found at doi: 10.1007/s00256-012-1483-5

B. Dallaudière $(\bowtie) \cdot J$. Lincot $\cdot$ E. Schouman-Claeys

Department of Medical Imaging, CHU Bichat - Claude Bernard, Assistance Publique - Hôpitaux de Paris,

46 Rue Henri Huchard,

75018 Paris, France

e-mail: benjamin.dallaudiere@gmail.com

J. Lincot

e-mail: julienlincot@gmail.com

E. Schouman-Claeys

e-mail: schouman.sec@bch.aphp.fr

B. Dallaudière $\cdot$ E. Schouman-Claeys

Faculté de Médecine Xavier Bichat, Université Paris Diderot, 16 Rue Henri Huchard,

75018 Paris, France

\section{A. Cotten}

Department of Musculoskeletal Imaging, Centre de Consultations et d'Imagerie de l'Appareil Locomoteur, CHRU de Lille,

Rue du Pr. Emile Laine,

59037 Lille Cedex, France

email: acotten@gmail.com

\section{A. Cotten}

Faculté de Médecine de Lille,

F-59045 Lille Cedex, France disease [1-3]. Thoracoabdominal CT demonstrated the classical spinal rugger jersey pattern of renal osteodystrophy [4].

Leontiasis ossea, also referred as "big-head" disease, is a progressively deforming craniofacial osteodystrophy. This rare polyostotic disorder is a consequence of the altered osseous metabolism encountered in advanced chronic kidney disease. The active metabolite of vitamin $\mathrm{D}[1,25(\mathrm{OH})$ 2D] is produced by renal tissue. Insufficiency results in hypocalcaemia which in turn stimulates secondary hyperparathyroidism $[5,6]$. The processes of resorption and formation become uncoupled, resulting in a spectrum of skeletal manifestations, including osteopenia, osteosclerosis, rickets in children, and osteomalacia in adults. With reduced renal function there is also phosphate retention, which results in an increase in the calcium $\times$ phosphorus product that may lead to metastatic precipitation of amorphous calcium phosphorus in soft tissues. Long-term hemodialysis can also alter bone homeostasis in other ways [4].

Leontiasis was the ancient description of the facial changes seen in leprosy due to chronic skin induration. The term ossea was originally added to imply that the pathogenesis of the facial hyperostosis was inflammatory. This term no longer has any pathogenic implication and has become purely descriptive [6]. When bone biopsy is carried out it usually shows medullary fibrosis, multiple osteoclastic resorption areas, and osteoblastic hyperactivity responsible for osteoid matrix formation. In typical presentations, biopsy is rarely necessary.

In our case the patient stated that his facial changes began after his renal failure. In addition, a facial CT scan done about a decade earlier had been reported as normal, excluding fibrous dysplasia.

Leontiasis ossea has been well-described in the literature, including in the pediatric population $[6,7]$. Severe involvement can be complicated by foraminal stenosis in the skull base possibly resulting in upper airway obstruction or cranial 
nerve compression such as facial palsy or hearing loss [8-10]. In those cases surgical nerve decompression must be considered. Treatment of chronic kidney disease with calcitriol can reduce the hypocalcaemic stimulus to secondary hyperparathyroidism. Total parathyroidectomy may slow or prevent development of leontiasis ossea [11].

\section{References}

1. Brooks JK, Rivera-Ramirez LE, Errington LW, Scheper MA. Synchronous Paget disease of bone and hyperparathyroidism: report of a case with extensive craniofacial involvement. Oral Surg Oral Med Oral Pathol Oral Radiol Endod. 2011;111(4):e19-24.

2. Maramattom BV. Leontiasis ossea and post traumatic cervical cord contusion in polyostotic fibrous dysplasia. Head Face Med. 2006;2:24

3. Eversole R, Su L, ElMofty S. Benign fibro-osseous lesions of the craniofacial complex. A review. Head Neck Pathol. 2008;2 (3):177-202.
4. Cotten A [avec la collaboration de Auger M, Bacqueville É, Boutry N, Ceugnart L, Chabi N, Cortet B, Dabbèche C, Da Silva $\mathrm{J}$, De Botton $\mathrm{S}$ et al]. Imagerie musculosquelettique pathologies générales. Issy-les-Moulineaux: Masson, 2005.

5. Chang JI, Som PM, Lawson W. Unique imaging findings in the facial bones of renal osteodystrophy. AJNR Am J Neuroradiol. 2007;28(4):608-9.

6. Lee VS, Webb MSJ, Martinez S, McKay CP, Leight GSJ. Uremic leontiasis ossea: "bighead" disease in humans? Radiologic, clinical, and pathologic features. Radiology. 1996;199(1):233-40.

7. Aggunlu L, Akpek S, Coskun B. Leontiasis ossea in a patient with hyperparathyroidism secondary to chronic renal failure. Pediatr Radiol. 2004;34(8):630-2.

8. Abid F, Lalani I, Zakaria A, Facchini SA, Hunter JV. Cranial nerve palsies in renal osteodystrophy. Pediatr Neurol. 2007;36(1):64-5.

9. Dentz ME, Lubarsky DA. Leontiasis ossea: an unusual presentation of a difficult airway. Anesth Analg. 1993;76(3):678-9.

10. Schmidt RH, Rietz LA, Patel BC, Osborne AG, Pratt D, Digre KB. Compressive optic neuropathy caused by renal osteodystrophy. Case report. J Neurosurg. 2001;95(4):704-9.

11. Zhang L, Yao L, Bian WJ, Rui HL. Severe uremic leontiasis ossea ameliorated by total parathyroidectomy. Kidney Int. 2009;76 (10):1118. 